\title{
QTL mapping for Mediterranean corn borer resistance in European flint germplasm using recombinant inbred lines
}

\author{
Bernardo Ordas*, Rosa A Malvar, Rogelio Santiago, Ana Butron
}

\begin{abstract}
Background: Ostrinia nubilalis (ECB) and Sesamia nonagrioides (MCB) are two maize stem borers which cause important losses in temperate maize production, but QTL analyses for corn borer resistance were mostly restricted to ECB resistance and maize materials genetically related (mapping populations derived from B73). Therefore, the objective of this work was to identify and characterize QTLS for MCB resistance and agronomic traits in a RILS population derived from European flint inbreds.

Results: Three QTLs were detected for stalk tunnel length at bins 1.02, 3.05 and 8.05 which explained 7.5\% of the RILs genotypic variance. The QTL at bin 3.05 was co-located to a QTL related to plant height and grain humidity and the QTL at bin 8.05 was located near a QTL related to yield.

Conclusions: Our results, when compared with results from other authors, suggest the presence of genes involved in cell wall biosynthesis or fortification with effects on resistance to different corn borer species and digestibility for dairy cattle. Particularly, we proposed five candidate genes related to cell wall characteristics which could explain the QTL for stalk tunnelling in the region 3.05. However, the small proportion of genotypic variance explained by the QTLs suggest that there are also many other genes of small effect regulating MCB resistance and we conclude that MAS seems not promising for this trait. Two QTLs detected for stalk tunnelling overlap with QTLs for agronomic traits, indicating the presence of pleitropism or linkage between genes affecting resistance and agronomic traits.
\end{abstract}

\section{Background}

Ostrinia nubilalis (ECB) and Sesamia nonagrioides $(\mathrm{MCB})$ are two maize stem borers which cause important losses in temperate maize production. ECB is present in United States and Central and South Europe, while Sesamia nonagrioides (MCB) is restricted to Mediterranean areas, including South Europe, North Africa and Middle East [1,2]. Larvae feed on the stem, producing tunnels that weaken the plant and, as consequence, stalk lodging is increased and yield reduced. Furthermore, larvae can also feed directly on the ear which promotes infections by Fusarium spp at levels that may affect human and animal health [3,4]. Although the type of damage caused by the two species is similar, $\mathrm{MCB}$ larvae are more voracious and produce more damage

* Correspondence: bernardo@mbg.cesga.es

Misión Biológica de Galicia, Spanish National Research Council (CSIC). Apartado 28, 36080 Pontevedra, Spain than ECB larvae [2]. Phenotypic evaluations for resistance to $\mathrm{ECB}$ and $\mathrm{MCB}$ suggest that maize has common mechanisms of resistance to both pests $[5,6]$.

Several studies have been carried out to map genetic factors for resistance to ECB tunnelling [7-9], but only one QTL analysis for resistance to MCB tunnelling has been reported so far [10]. The two QTLs for MCB resistance detected were located close to QTLs for ECB resistance which could indicate the presence of gene clusters or common mechanisms of resistance to different pests. However, more QTL experiments for resistance to MCB are needed to confirm the co-localization of QTLs for resistance to both pests. The search for QTLs rather should be done with no previously prospected maize materials than with materials extensively studied such as those derived from B73 [7-10] in order to likely increase the number of known genomic regions 
involved in borer resistance, as, in general, different subsets of QTLs can segregate in different populations [11].

Significant variation for resistance to ECB and MCB was found in the European Union Maize Landrace Core collection and some populations from Central and Eastern Spain seemed to be promising sources of resistance to maize stem borers, that is, those populations probably carry favourable alleles for ECB or MCB resistance [5,12,13]. Consequently, the use of mapping populations derived from these European materials could allow to widen the already known genomic regions for corn borer resistance.

Additive effects have been consistently reported as more important than dominant effects for stalk tunnelling by MCB [14-16], while additive and dominant effects has been reported as important for $\mathrm{MCB}$ ear resistance and yield under infestation $[17,18]$. It is interesting to mention that stalk tunnel length, the character typically used to quantify corn borer damage, is negatively correlated with yield [19-21], although the genetic mechanism responsible of that relationship, whether pleitropy or repulsion linkage, is unknown. A population of recombinant inbred lines (RILs) is a useful tool for mapping QTLs for traits under additive control because RILs represent a permanent sample of progenies for evaluations using replications in different environments.

Most inbreds used in temperate zones derive from Corn Belt Dent varieties, but adapted flint lines derived from European populations are also widely used, particularly, in Europe, northern areas of North America, and Japan [22-25]. A heterotic pattern widely used by western European breeders is Corn Belt Dent $\times$ European Flint [23,26-28] using preferentially materials from the Still Stalk Synthetic because the Stiff Stalk Synthetic subgroup shows more heterosis with European Flint than other Corn Belt Dent subgroups [26]. A population of RILs derived from two European flint lines will be used to address the objectives: (1) to estimate the genetic correlations between MCB resistance and agronomic traits; (2) to identify and characterize QTLs responsible for $\mathrm{MCB}$ resistance and agronomic traits within the European Flint group.

\section{Results}

EP42 had higher stalk tunnel length than EP39, while EP39 $\times$ EP42 had a value close to the mid-parent value (Table 1). In contrast to stem resistance, EP39 $\times$ EP42 had higher level of ear resistance than the most resistance parent. The average value of the RILs was close to the mid-parent value for several traits, either agronomic or related to resistance. Genetic variances in the RIL population were highly significant for all traits, while the genotype $x$ environment interaction variances were highly significant for agronomic traits, but not for resistance traits, except for cob damage.

Regarding the agronomic traits, a negative genetic correlation coefficient between flowering and yield was found among RILs, while a positive genetic correlation coefficient was found between flowering and grain humidity (Table 2). Regarding the relationship between agronomic and resistant traits, plant height and flowering had a positive and moderate genetic relationship with stalk tunnel length.

The genetic map had a total length of $1791 \mathrm{cM}$ and an average distance between loci of about $20 \mathrm{cM}$ (Figure 1). In the RILs, three QTLs were detected for stalk tunnel length at chromosomes 1, 3 and 8 (Figure 1; Table 3). Those QTLs explained 33\% of the genetic variance, calculated with the whole data set, but this value was reduced to $7.5 \%$ when the cross validation method was used. The additive values for the QTLs varied between

Table 1 Characteristics of EP39 and EP42, EP42 $\times$ EP39 and the RIL population developed from EP42 $\times$ EP39.

\begin{tabular}{llllllll}
\hline & \multicolumn{9}{c}{ Means } & \multicolumn{3}{l}{ Variances } \\
\cline { 2 - 8 } Stalk tunnel length (cm) & EP39 & EP42 & F1 & RILs & $\sigma_{g}^{2}$ & $\sigma_{g e}^{2}$ & $\sigma_{e}^{2}$ \\
\cline { 2 - 8 } & $19.9 \pm 5.5$ & $54.9 \pm 5.5$ & $43.4 \pm 4.0$ & $38.9 \pm 4.0$ & $39.3 \pm 8.0^{* *}$ & $11.8 \pm 6.6$ & $101.6 \pm 6.3^{* *}$ \\
\hline Relative stalk tunnel length & $0.38 \pm 0.11$ & $0.51 \pm 0.11$ & $0.32 \pm 0.03$ & $0.42 \pm 0.07$ & $0.0016 \pm 0.0006^{* *}$ & $0.0013 \pm 0.0007$ & $0.01125 \pm 0.0007^{* *}$ \\
\hline Kernel damage (1-9 scale) & $6.67 \pm 0.58$ & $6.82 \pm 0.59$ & $8.43 \pm 0.16$ & $7.38 \pm 0.12$ & $0.098 \pm 0.0557$ & $0.080 \pm 0.070$ & $1.148 \pm 0.073^{* *}$ \\
\hline Shank damage (1-9 scale) $)^{a}$ & $3.09 \pm 0.37$ & $3.90 \pm 0.37$ & $5.97 \pm 0.69$ & $4.05 \pm 0.43$ & $0.55 \pm 0.17^{* *}$ & $0.00 \pm 0.00$ & $2.68 \pm 0.20^{* *}$ \\
\hline Cob damage (1-9 scale) $^{a}$ & $5.33 \pm 0.35$ & $7.37 \pm 0.35$ & $8.50 \pm 0.10$ & $7.53 \pm 0.21$ & $0.632 \pm 0.123^{* *}$ & $0.041 \pm 0.003^{* *}$ & $1.217 \pm 0.093^{* *}$ \\
\hline Anthesis (days) & $64.6 \pm 7.4$ & $66.3 \pm 7.4$ & $59.2 \pm 6.1$ & $66.8 \pm 7.2$ & $7.88 \pm 1.02^{* *}$ & $1.23 \pm 0.35^{* *}$ & $4.23 \pm 0.26^{* *}$ \\
\hline Silking (days) & $67.3 \pm 6.5$ & $67.6 \pm 6.5$ & $61.3 \pm 5.7$ & $68.8 \pm 6.3$ & $9.05 \pm 1.25^{* *}$ & $2.31 \pm 0.52^{* *}$ & $5.26 \pm 0.32^{* *}$ \\
\hline Plant height (cm) & $56.4 \pm 4.0$ & $109.7 \pm 4.0$ & $132.5 \pm 7.8$ & $93.7 \pm 4.2$ & $121.2 \pm 18.0^{* *}$ & $26.5 \pm 9.6^{* *}$ & $126.8 \pm 7.9^{* *}$ \\
\hline Grain humidity (\%) & $18.9 \pm 0.7$ & $15.5 \pm 0.7$ & $19.4 \pm 0.3$ & $17.8 \pm 0.3$ & $0.82 \pm 0.33^{* *}$ & $1.59 \pm 0.35^{* *}$ & $3.46 \pm 0.21^{* *}$ \\
\hline Yield (t ha ${ }^{-1}$ ) & $0.93 \pm 0.25$ & $2.51 \pm 0.25$ & $6.67 \pm 0.96$ & $1.80 \pm 0.24$ & $0.37 \pm 0.08^{* *}$ & $0.26 \pm 0.06^{* *}$ & $0.64 \pm 0.04^{* *}$ \\
\hline
\end{tabular}

Estimates of means \pm standard deviation, as well as of variance components were obtained for several agronomic and resistance traits after evaluation in two environments under artificial infestation with corn borer eggs

a Kernel, Shank and cob damages were estimated on a 9 point scale $(9=$ without injury; $1=$ wholly damaged $)$

** Variance component was significant at the 0.01 probability level 
Table 2 Phenotypic and genetic correlation coefficients among resistance and agronomic traits calculated in the population of RILs derived from EP39 $\times$ EP42.

\begin{tabular}{llllllllll}
\hline & AT $^{\mathrm{a}}$ & $\mathrm{S}$ & $\mathrm{PH}$ & $\mathrm{H}$ & $\mathrm{Y}$ & $\mathrm{STL}$ & $\mathrm{RSTL}$ & $\mathrm{SDR}$ & $\mathrm{CDR}$ \\
\hline AT & & $0.92^{*}$ & 0.01 & $0.32^{*}$ & $-0.36^{*}$ & $0.10^{*}$ & $0.11^{*}$ & $-0.11^{*}$ & $-0.21^{*}$ \\
$\mathrm{~S}$ & $0.97^{+}$ & & -0.01 & $0.32^{*}$ & $-0.42^{*}$ & $0.11^{*}$ & $0.13^{*}$ & $-0.12^{*}$ & $-0.20^{*}$ \\
$\mathrm{PH}$ & $0.23^{+}$ & 0.20 & & 0.07 & $0.37^{*}$ & $0.48^{*}$ & -0.05 & $0.15^{*}$ & 0.05 \\
$\mathrm{H}$ & $0.85^{+}$ & $0.74^{+}$ & 0.53 & & $-0.14^{*}$ & 0.07 & 0.05 & 0.01 & $-0.20^{*}$ \\
Y & $-0.68^{+}$ & $-0.68^{+}$ & 0.27 & -0.84 & & $0.12^{*}$ & -0.07 & $0.17^{*}$ & 0.16 \\
$\mathrm{STL}$ & $0.32^{+}$ & $0.43^{+}$ & $0.51^{+}$ & 0.61 & -0.03 & & $0.82^{*}$ & $-0.25^{*}$ & -0.18 \\
RSTL & 0.19 & $0.38^{+}$ & -0.28 & 0.29 & -0.35 & $0.70^{+}$ & & $-0.37^{*}$ & $-0.24^{*}$ \\
SDR & -0.44 & $-0.53^{+}$ & 0.12 & - & -0.19 & -0.08 & -0.09 & & $0.51^{*}$ \\
CDR & -0.76 & -0.41 & 0.56 & - & 0.22 & 0.94 & 0.58 & $0.68^{+}$ & \\
\hline
\end{tabular}

The phenotypic correlation coefficients are shown above the diagonal while the genetic correlation coefficients are shown below the diagonal. The correlation coefficients were obtained after evaluation in two environments under artificial selection with corn borer eggs

${ }^{a} \mathrm{AT}=$ anthesis, $\mathrm{S}=$ silking, $\mathrm{PH}=$ plant height, $\mathrm{H}=$ grain humidity, $\mathrm{Y}=$ yield $\mathrm{STL}=$ stalk tunnel length, $\mathrm{RSTL}=$ relative stalk tunnel length, $\mathrm{SDR}=$ shank damage rating, $C D R=$ cob damage rating.

* Phenotypic correlation was significant at the 0.01 probability level.

${ }^{+}$Genotypic correlation exceeded twice its standard error.

2.4 and $2.8 \mathrm{~cm}$ and both parents contributed with favourable alleles. The QTL at bin 8.05 was also related to relative stalk tunnel length. Concerning ear resistance traits, one QTL was detected for cob damage rate with a LOD score lower than 3 and a validation frequency lower than 30\%.1",5,"not_at_top">

In the RILs, we also detected 6, 1, 1, and 4 QTLs for silking, plant height, kernel humidity, and yield, respectively (Figure 1; Table 3). For these traits, the percentage of genetic variance explained by the QTLs, calculated in the whole data set, varied from 10 to $45 \%$. However, the percentages of genetic variance explained by the QTLs were much lower when they were calculated by cross validation. The QTL for silking at bin 8.05 is remarkable because it explains $29 \%$ of the phenotypic variance. This QTL was detected for silking in the $92 \%$ of the CV/G runs, indicating a great precision in the location. A QTL for yield at bin 8.05 was located near a QTL related to stalk tunnel length and relative stalk tunnel length. A QTL for plant height and grain humidity was found at bin 3.05 and explained $16 \%$ of the phenotypic variance, approximately, for each trait. For both traits, the QTL was detected with great precision (more than 95\% of the $\mathrm{CV} / \mathrm{G}$ runs). For silking, each parent contributed with favourable alleles to half of the QTLs, while for yield, the favourable alleles for most QTLs came from EP42. EP42 also provided the allele that increased the trait for the QTL related to plant height and kernel humidity.

\section{Discussion}

As expected from previous experiments [29,30] EP39 was resistant, while EP42 was susceptible to MCB stalk tunnelling. The value of EP39 $\times$ EP42 for stalk tunnel length was close to the mid-parent value which suggests that additive effects were more important than dominant effects. This is in concordance with previous experiments in which the dominant effects were not significant, except for one single cross [14-16]. Contrarily to stalk tunnel length, the hybrid was more ear resistant than the most resistant line indicating that dominant effects would also play an important role, in agreement with results reported by Cartea et al. [18] and Velasco et al. [31]. Similarly, the EP39 $\times$ EP42 hybrid exhibited a considerable degree of heterosis for most agronomic traits. Although both parental lines did not differ for many traits, the significant genetic variation found among RILs for all traits, except for kernel damage, showed that this population is a valuable material to detect QTLs among European germplasm, especially for MCB resistance. The lack of significant RILs $\times$ environment interaction for stalk tunnel length is in agreement with previous research [10,29,32].

Plant height was highly and significantly correlated to a resistance trait, such as stalk tunnel length. This result is in agreement with the result reported by Schon et al. [33], but not with results obtained by other authors [7,9,34]. This suggests that the genetic relationship between both traits depends on the germplasm being evaluated.

The 3 QTLs for stalk tunnelling by MCB detected in this study did not overlap with the QTLs for stalk tunnelling by MCB detected in the intermated B73 $\times$ Mo17 population [10]. Differences due to genetic heterogeneity or sampling limited number of progeny could explain the lack of coincidence between two particular QTL experiments. On the contrary, the QTLs for stalk tunnelling detected in the present study were in the same or adjacent bins to QTLs for stalk tunnelling by ECB consistently detected in other experiments [7-9,33-35]. The coincidence of the three QTL locations in experiments carried out with genetically diverse maize populations and with different corn borer species indicates the importance of those genomic regions for corn borer resistance across corn borer species and maize populations. The resistance mechanisms of maize to ECB or MCB attack at early stages of plant development are probably based on toxins, for example DIMBOA, but, based on structural compounds, particularly cell wall composition, later on [36-39]. Cell wall characteristics may affect insect feeding due to different reasons: elevated levels of indigestible fiber may increase the bulk density of the diet to the point that insect are unable to ingest sufficient quantities of nutrients and water [40], and/or lignified cell walls may produce tougher tissues that are more resistant to the tearing action of mandibles [41]. QTLs for MCB stalk tunnelling detected in this experiment at bins $1.02,3.05$, and 8.04 were close 


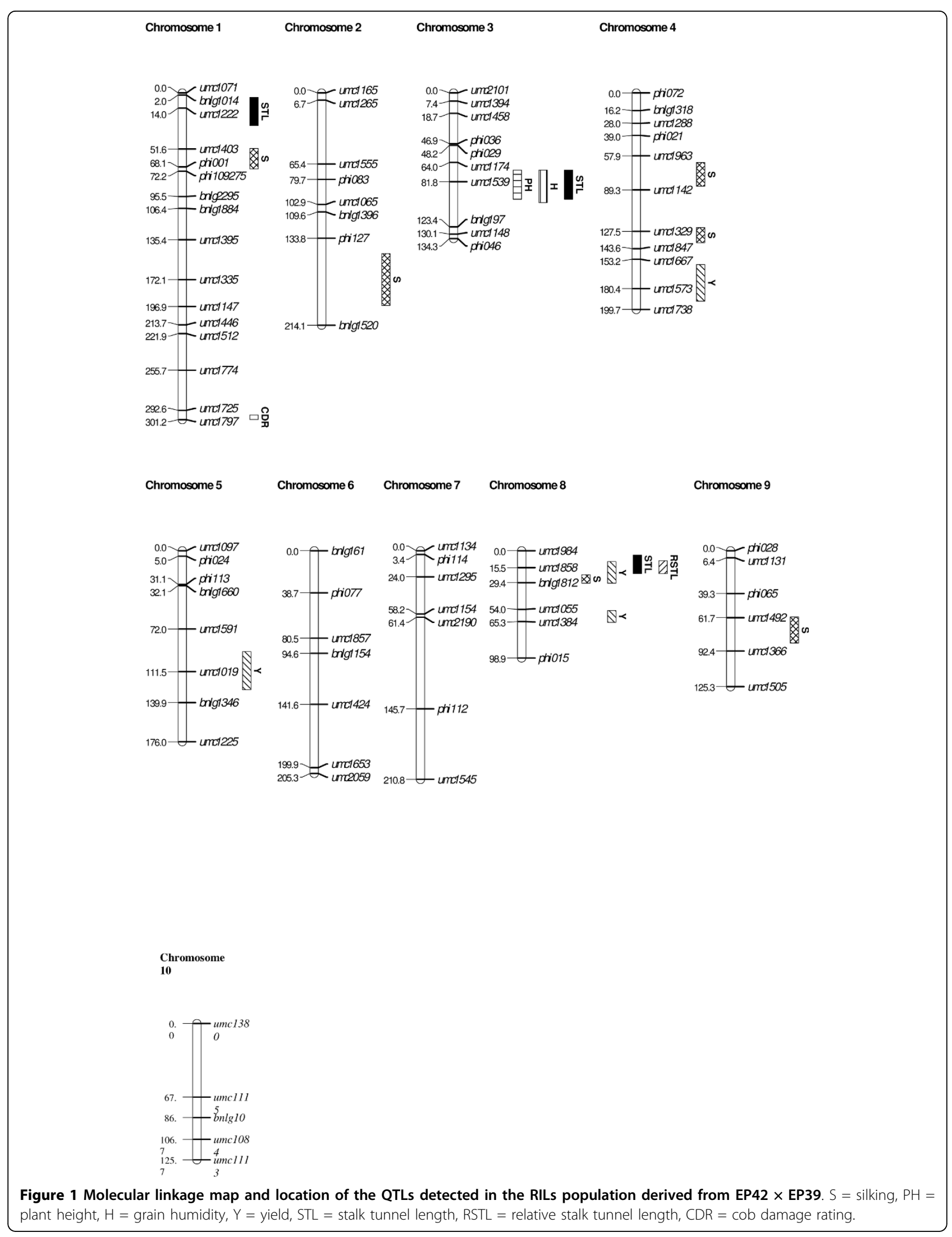


Table 3 Summary of QTLs detected in the RIL population derived from a EP39 $\times$ EP42 evaluated in two environments under artificial infestation with corn borer eggs.

\begin{tabular}{|c|c|c|c|c|c|c|c|c|c|c|}
\hline \multirow[b]{2}{*}{ QTL bin ${ }^{a}$} & \multirow[b]{2}{*}{ Confidence interval } & \multirow[b]{2}{*}{ LOD score } & \multirow[b]{2}{*}{ Flanking markers } & \multirow[b]{2}{*}{$R_{\text {adj }}^{2}$} & \multirow[b]{2}{*}{$p^{\mathrm{b}}$} & \multirow[b]{2}{*}{$\hat{a}^{c}$} & \multicolumn{4}{|c|}{ Cross validation $\hat{a}_{\text {TS.ES }}{ }^{d}$} \\
\hline & & & & & & & Median & Percentile $(10,90)$ & Frequency (\%) & $\mathrm{P}$ \\
\hline \multicolumn{11}{|c|}{ Stalk tunnel length $(\mathrm{cm})$} \\
\hline 1.02 & $4-30$ & 4.25 & $\begin{array}{l}\text { bnlg1014 } \\
\text { umc1222 }\end{array}$ & 11.6 & & -2.83 & -2.85 & $(-3.33,-2.42)$ & 91.9 & \\
\hline 3.05 & $71-98$ & 3.87 & $\begin{array}{l}\text { umc1174 } \\
\text { umc1539 }\end{array}$ & 9.6 & & 2.40 & 2.47 & $(2.14,3.01)$ & 78.7 & \\
\hline 8.05 & $4-21$ & 3.46 & $\begin{array}{l}\text { umc1984 } \\
\text { umc1858 }\end{array}$ & 9.6 & & 2.57 & 2.63 & $(2.22,3.22)$ & 77.7 & \\
\hline Final fit & & & & & 33.2 & & & & & 8.7 \\
\hline \multicolumn{11}{|c|}{ Relative stalk tunnel length } \\
\hline 8.05 & $9-21$ & 4.91 & $\begin{array}{l}\text { umc1984 } \\
\text { umc1858 }\end{array}$ & 15.0 & & 0.02 & 0.02 & $(0.018,0.027)$ & 65.0 & \\
\hline Final fit & & & & & 28.4 & & & & & 0.0 \\
\hline \multicolumn{11}{|c|}{ Cob damage (1-9 scale $)^{e}$} \\
\hline 1.12 & 297-301 & 2.54 & $\begin{array}{l}\text { umc1725 } \\
\text { umc1797 }\end{array}$ & 7.5 & & 0.29 & 0.33 & $(0.29,0.37)$ & 29.0 & \\
\hline Final fit & & & & & 7.0 & & & & & 0.0 \\
\hline \multicolumn{11}{|c|}{ Silking (days) } \\
\hline 1.03 & $51-70$ & 3.22 & $\begin{array}{l}\text { umc1003 } \\
\text { phi001 }\end{array}$ & 9.5 & & -0.94 & -0.98 & $(-1.19,-0.85)$ & 34.9 & \\
\hline 2.08 & $148-196$ & 3.48 & $\begin{array}{l}\text { phi127 } \\
\text { bnlg1520 }\end{array}$ & 11.2 & & 2.11 & 2.19 & $(1.86,2.63)$ & 50.4 & \\
\hline 4.04 & $64-86$ & 4.87 & $\begin{array}{l}\text { umc1963 } \\
\text { umc1142 }\end{array}$ & 13.7 & & 1.58 & 1.43 & $(1.19,1.71)$ & 55.3 & \\
\hline 4.06 & $124-138$ & 2.80 & $\begin{array}{l}\text { umc1329 } \\
\text { umc1847 }\end{array}$ & 8.2 & & -0.87 & -1.07 & $(-1.29,-0.91)$ & 59.7 & \\
\hline 8.05 & $22-30$ & 10.8 & $\begin{array}{l}\text { umc1858 } \\
\text { bnlg1812 }\end{array}$ & 29.4 & & -1.62 & -1.41 & $(-1.64,-1.13)$ & 92.1 & \\
\hline 9.05 & $61-85$ & 5.49 & $\begin{array}{l}\text { umc1492 } \\
\text { bnlg1812 }\end{array}$ & 15.9 & & 1.35 & 1.27 & $(1.06,1.55)$ & 63.3 & \\
\hline Final fit & & & & & 45.5 & & & & & 18.9 \\
\hline \multicolumn{11}{|c|}{ Plant height $(\mathrm{cm})$} \\
\hline 3.05 & $71-98$ & 5.97 & $\begin{array}{l}\text { umc1174 } \\
\text { umc1539 }\end{array}$ & 16.6 & & 5.04 & 5.27 & $(4.18,6.94)$ & 98.4 & \\
\hline Final fit & & & & & 16.1 & & & & & 12.8 \\
\hline \multicolumn{11}{|c|}{ Grain humidity (\%) } \\
\hline 3.05 & $71-101$ & 5.60 & $\begin{array}{l}\text { umc1539 } \\
\text { bnlg197 }\end{array}$ & 16.0 & & 0.63 & 0.66 & $(0.51,0.89)$ & 95.8 & \\
\hline Final fit & & & & & 11.7 & & & & & 0.7 \\
\hline \multicolumn{11}{|c|}{ Yield $\left(\mathrm{t} \mathrm{ha}^{-1}\right)$} \\
\hline 4.08 & 158-192 & 2.44 & $\begin{array}{l}\text { umc1667 } \\
\text { umc1573 }\end{array}$ & 7.3 & & 0.21 & 0.22 & $(0.18,0.26)$ & 36.5 & \\
\hline 5.05 & $93-128$ & 2.85 & $\begin{array}{l}\text { umc1591 } \\
\text { umc1019 }\end{array}$ & 8.5 & & -0.18 & -0.22 & $(-0.28,-0.19)$ & 44.6 & \\
\hline 8.05 & $10-30$ & 3.46 & $\begin{array}{l}\text { umc1858 } \\
\text { bnlg1821 }\end{array}$ & 10.3 & & 0.23 & 0.23 & $(0.20,0.28)$ & 39.8 & \\
\hline 8.08 & $55-66$ & 4.07 & $\begin{array}{l}\text { umc1055 } \\
\text { umc1384 }\end{array}$ & 12.5 & & 0.25 & 0.24 & $(0.20,0.32)$ & 51.4 & \\
\hline Final fit & & & & & 22.5 & & & & & 9.06 \\
\hline
\end{tabular}


to QTLs for stalk strength or cell wall compounds detected in other experiments, suggesting that genes involved in the synthesis of cell wall compounds in maize could be good candidate genes for resistance to corn borers. Thus, Flint-Garcia et al. [42] detected only one QTL for stalk strength in common across four populations which is approximately located in bin 3.05. Regarding cell wall main components, QTLs for neutral detergent fiber (NDF), acid detergent fiber (ADF), acid detergent lignin (ADL) and hemicellulose were detected in bins 1.01/1.02, 3.05/3.06 and 8.03/8.04 [43-47]. In addition, Barriere et al. [43] found cell wall-bound phenolic compounds ( $\mathrm{p}$-coumaric acid, esterified ferulic acid, etc) to be associated to the three genomic regions, particularly to bin $1.01 / 1.02$. Silage corn digestibility for dairy cattle is related to cell wall characteristics [48] and therefore probably related to maize resistance to corn borers too. Thus, QTLs for silage corn digestibility were also detected in bins 1.01/1.02 and 3.05/3.06 [43,49]. Furthermore, out of the five expression QTL (eQTL) hotspots for silage corn digestibility detected by Shi et al. [50], the two main ones were in bins 8.03 and 3.05 . The eQTL hotspot on bin 3.05 was co-localized with a QTL for cell wall digestibility, concluding the authors that the gene underlying QTL and eQTL are identical.

In the region of bin 3.05 approximately 1000 proteincoding genes of rice and sorghum aligned to maize genome http://www.plantgdb.org/ZmGDB/DisplayGeneAnn. $\mathrm{php} ? \mathrm{ds}=\& \mathrm{q}=$. For that reason, the isogenization-assisted by molecular markers - of the QTL could narrow its interval and facilitate the clonation of genes. However, we propose some candidate genes according to the hypothesis that genes involved in cell wall biosynthesis or fortification confer also resistance to corn borers. Candidate genes for stem tunnelling were selected from the gene expression data repertory of cell wall biosynthesis and assembly in maize contained in MAIZEWALL http://www.polebio.scsv.ups-tlse.fr/MAIZEWALL/index. $\mathrm{html}$, the genes located in those QTL regions. We have found in the region 3.05 three genes from the phenyhlpropanoid pathway which is the pathway that controls the biosynthesis of monolignols, the monomers of lignins [51]. These genes are: a peroxidase (GRMZM2G103342, ctg126, AC211202: 70944-73152, http://www.maizesequence.org/Zea_mays2/geneview? $\mathrm{db}=$ core;gene $=$ GRMZM2G103342), a laccase (GRMZM2G072780, ctg137, AC207620: 82019-85418, http://www.maizesequence.org/Zea_mays2/geneview? $\mathrm{db}=$ core; gene $=$ GRMZM2G072780), and a $\mathrm{p}$-coumarate3-hydroxylase (C3H) (GRMZM2G138074, ctg138, AC200558: 57765-60725, http://www.maizesequence. org/Zea_mays2/geneview?db=core;gen$\mathrm{e}=$ GRMZM2G138074). In addition to the MAIZEWALL repertory of genes, we also searched in MaizeGDB for genes related to cell wall biosynthesis located at the QTLs' regions. In bin 3.05 lies a gene that codifies for the sucrose phosphate synthase 2 enzyme (ctg 131, between position 152605600 and 152708500 , http:// www.maizegdb.org/cgi-bin/displaylocusrecord.cgi? $\mathrm{id}=96665)$ which is involved in cellulose biosynthesis [52]. The lax midrib1 gene which affects the midrib portion of the leaf [53] is also in the region (ctg 132, between position 161945000 and 163130800 , http:// www.maizegdb.org/cgi-bin/displaylocusrecord.cgi? $\mathrm{id}=12405$ ). Inbred lines of maize with lax midribs have lower levels of fiber, lignin and xylose and are more digestible than 'normal' inbreds [54]. The five genes at bin 3.05 constitute possible candidate genes for resistance to stalk tunneling that could be validated by an association study [55].

For stalk tunnel length the proportion of genotypic variance explained by the QTLs following cross validation in our experiment was similar to that found by Papst et al. [34] and Ordas et al. [10]. Given the low number of detected QTL and the small proportion of genotypic variance explained, it is likely that the trait be regulated by many QTL of small effect. Therefore, according to different QTL experiments, for resistance to corn borer tunnelling the theoretical expectation of the efficacy of MAS for increasing resistance to corn borers is low and it can be concluded that MAS seems not promising. However, the genomic regions related to resistance to corn borer detected in this and others QTL experiments are useful as start points for fine mapping in order to address, in the future, the cloning of genes related to resistance. Regarding the utility of the QTLs for maize breeding, we evaluated a sample of 118 of the RILs crossed to a tester (A641) in two different sowing dates in the same location and year (data not shown), and no QTLs for resistance were found in the testcross population.

We found, consistently with a previous experiment with MCB [10], that MCB produce higher tunnels length than ECB $[7,9,35]$. In both experiments with MCB we found less QTLs for stalk tunnelling, 3 and 2 respectively, than the average number of QTLs reported for ECB stalk tunneling that ranged from six to nine [7,8,33-35]. As argued by Ordas et al. [10], it is possible that, due to the aggressiveness of the insect, most genotypes seem to be susceptible, although some of them carry a low level of resistance. This is in agreement with the phenotypic performance of the two parents and the segregation among RILs.

Regarding the agronomic traits, the major QTL for flowering time detected at bin 8.05 is located within a consensus region of major effect [56] with at least two different QTLs: vgt1, recently cloned by Salvi et al. [57] and $v g t 2$ [58]. The confidence interval of this QTL for 
flowering time overlapped with the confidence interval of a QTL for yield. As the allele that increased flowering time decreased yield, the co-localization of the two QTLs could partially explain the significant and negative genetic correlations between flowering time and yield that we found. The QTL for plant height at bin 3.05 was consistently found in different genetic backgrounds and environments [7,33,59-62]. The confidence interval of this QTL overlapped with the confidence interval of the QTL for stalk tunnel length, agreeing with a previous experiment [33]. Furthermore, in both experiments the allele associated to increased damage was also associated to increased plant height. The co-localization of the two QTLs, for plant height and stalk tunnel length, could contribute to the positive genetic correlation between both traits detected in this experiment. The confidence interval of the QTL for yield at bin 8.05 overlapped with the confidence interval of a QTL for stalk tunnel length and relative stalk tunnel length. Both the allele for decreased yield and the allele for increased stalk resistance were provided by the same line and, therefore, if the QTL would be used for increasing resistance to corn borers by MAS, a negative effect on yield could be expected. A negative relationship between resistance and yield was also found in selection programs in which the yield decreased as an indirect consequence of selecting for increased resistance [19-21]. However, it is not possible to know if the co-localization of QTLs for different traits is due to linkage between different genes or pleitropism of a single gene.

\section{Conclusions}

We detected three genomic regions involved in resistance to stalk tunnelling by MCB that were close to genomic regions related to resistance to stalk tunnelling by ECB detected in genetically different populations. This indicates the importance of those genomic regions across corn borer species and maize populations. Our results, when compared with results from other authors, suggest that genes involved in cell wall biosynthesis or fortification could be good candidate genes for the QTLs detected for stem tunnelling in our experiment. Particularly, we proposed five candidate genes related to cell wall characteristics which could explain the QTL for stalk tunnelling at bin 3.05. The small proportion of genotypic variance explained by the QTLs suggest that there are also many other genes of small effect regulating stem tunnelling by MCB. Therefore, we conclude that MAS seems not promising for this trait, although the genomic regions consistently detected are useful as starting points for the cloning of genes related to resistance. Two of the QTLs detected for stalk tunnelling overlap with QTLs for agronomic traits, indicating the presence of pleitropism or linkage between genes.

\section{Methods \\ Plant materials}

We developed a population of 178 RILs from the cross EP42 $\times$ EP39 by single-seed descent. EP42 is a yellow European flint line that was obtained from a local open pollinated variety from North-Western Spain (humid Spain), while EP39 is a yellow European flint line that was obtained from the race 'Fino' from Central Spain (dry Spain). EP42 is susceptible to MCB tunnelling, while EP39 is resistant to MCB attack [29,30]. The seed of the RILs was obtained by hand pollination in Northwestern Spain in 2005.

\section{Phenotypic analysis}

The parental inbred lines, the RILs, and EP39 $\times$ EP42 were evaluated in 2006 and 2007 in Pontevedra (42 $\left.30^{\prime} \mathrm{N}, 8^{\circ} 46^{\prime} \mathrm{W}\right)$, located in Northwestern Spain at the sea level, on the Atlantic coast. In Pontevedra, temperatures are relatively mild all year and the average annual rainfall is around $1700 \mathrm{~mm}$. The evaluation was carried out under artificial infestation with corn borer eggs. At each environment, the treatments were arranged in a $16 \times 12$ $\alpha$-lattice design with three replications per environment. For the evaluation of the RILs each plot consisted of one row with 13 hills per plot, rows were spaced $0.80 \mathrm{~m}$ apart and hills were spaced $0.21 \mathrm{~m}$ apart. Plots were overplanted and thinned obtaining a final density of approximately 60000 plants ha $^{-1}$. The seedbed preparation was made according to the standard practices of the area: a chisel plow followed by a rotary tiller. Prior to emergence a pre-emergence herbicide was applied. When the plants were about $60 \mathrm{~cm}$ tall, later weeds were controlled by cultivation with a shovel cultivator. Fertilization was made with $105 \mathrm{Kg}$ of $\mathrm{N}, 105 \mathrm{Kg}$ of $\mathrm{P}_{2} \mathrm{O}_{5}$, and $105 \mathrm{Kg}$ of $\mathrm{K}_{2} \mathrm{O}$. Prior to flowering we applied 55 additional $\mathrm{Kg}$ of $\mathrm{N}$. We irrigated with $60 \mathrm{~L} \mathrm{~m}^{-2}$ at flowering.

For each plot, the date of silking was considered when $50 \%$ of the plants of the plot exerted the silks from within the husks. At silking, five plants for each plot were infested with a mass of $\approx 40$ eggs of corn borer which were placed between the main ear and the stem [63]. At harvest, stems of the infested plants from each plot were dissected, the total tunnel length $(\mathrm{cm})$ of each plant measured and the corn borer tunnelling reported both in centimetres (stalk tunnel length) and as ratio of tunnel length and plant height (relative stalk tunnel length). Kernel damage was estimated on a 9 point scale ( 9 = without injury; 1 = wholly damaged). The following agronomic traits were also taken: the number of days 
from the date of planting to the date of anthesis, plant height, grain humidity at harvest (\%), and yield at $140 \mathrm{~g}$ $\mathrm{kg}^{-1}$ moisture content. In addition to the previous traits, shank and cob damage ratings $(9=$ without injury; $1=$ wholly damaged) were estimated for each plot.

Individual analyses of variance and adjusted means were calculated for all traits according to a $\alpha$-lattice design using the Mixed Procedure of SAS [64]. Combined analysis of variance over years was computed using the adjusted means. Variance components were estimated by restricted maximum likelihood (REML). Computations were performed with SAS [64]. Phenotypic $\left(r_{p}\right)$ and genetic $\left(r_{g}\right)$ correlations between traits were estimated with a multivariate REML procedure following Holland [65] and using the SAS programs developed by the author http://www4.ncsu.edu/ jholland/correlation/ correlation.html.

\section{QTL analysis}

DNA of ten plants picked at random from each RIL was extracted according to Liu and Whittier [66] with modifications. SSR amplifications were performed as described by Butron et al. [67]. SSR products were separated after amplification by electrophoresis using $1 \mathrm{TBE}$ on a $6 \%$ non-denaturing acrylamide gel (approximately $250 \mathrm{~V}$ for $3 \mathrm{~h}$ ) [68]. Two hundred twenty six SSR primers pairs were used to genotype the RILs. From these, eighty four SSR that were polymorphic and give clear bands patterns were used for linkage mapping and QTL analysis, resulting in a uniform distribution of markers along the genome. The linkage map was built using MAPMAKER 3.0b [69]. Loci were assigned to linkage groups which were anchored to chromosomes using default parameters (minimum LOD of 3.00, maximum distance of $30 \mathrm{cM}$ and maximum unlinked LOD of 2.00). Multipoint linkage analysis was performed for each linkage group by the "order" command using an informativeness criteria of 100 individual and a distance between markers of $2.00 \mathrm{cM}$. Charts of chromosomes and QTLs were obtained by using MapChart [70]. Composite interval mapping [71] was conducted with PLABQTL [72] with cofactor selection performed following PLABQTL's recommendations and using an " $F$ to-enter" and an " $F$-to-delete" value of 7 . A LOD threshold of 2.4 was determined by permutation tests that ensures an experiment wise error rate of $p<0.20$. A simultaneous fit with the detected QTLs was performed for each environment and a QTL ANOVA was carried out with PLABQTL [73]. The mean squares of the ANOVA were used to obtain an estimate of the proportion of the genetic variante explained by the detected QTL which is adjusted by QTL $\times$ environment interaction [73].
Fivefold cross validation (CV/G) was performed, following the procedures described by Utz et al. [74], to estimate the additive effects and the proportion of genotypic variance explained by the QTLs. The whole data set was randomly split into $k=5$ data subsets. Four of these subsets were combined to form the estimation set (ES) and the remaining subset formed the test set (TS) in which predictions derived from ES were tested for their validity by correlating predicted and observed data. We used 1000 replicated CV/G runs. For a particular QTL and its confidence interval estimated using the whole data set, the frequency of QTL detection across the CV/ $\mathrm{G}$ runs was calculated by counting the number of $\mathrm{CV} / \mathrm{G}$ runs in which a QTL was located within that confidence interval. The frequency of QTL detection gives us an estimation of the precision of QTL localization [73].

\section{Acknowledgements \\ This research was supported by the National Plan for Research and Development of Spain (Project Cod. AGL2006-13140). B Ordas and Rogelio Santiago acknowledge a contract from the Xunta the Galicia (Isidro Parga Pondal program) and from the Spanish Ministry for Science and Innovation (Juan de la Cierva program), respectively.}

\section{Authors' contributions}

BO carried out field experiments, performed data analysis and drafted the manuscript. RAM conceived the study, participated in its design and in its coordination. RS assisted BO in field experiments. AB conceived the study, participated in its design, carried out molecular analysis and assisted BO in data analysis. All authors read and approved the final manuscript.

Received: 6 October 2009

Accepted: 15 March 2010 Published: 15 March 2010

\section{References}

1. Malvar RA, Butron A, Revilla P, Ordas A: Resistance to the pink stem borer, Sesamia nonagrioides, in maize. Recent Res Devel Plant Sci Kerala (India), Research SignpostPandallai SG 2004, 1-32.

2. Velasco P, Revilla P, Monetti L, Butron A, Ordas A, Malvar RA: Corn borers (Lepidoptera: Noctuidae, Crambidae) in Northwestern Spain: Population dynamics and distribution. Maydica 2007, 52:195-203.

3. Avantaggiato G, Quaranta F, Desiderio E, Visconti V: Fumonisin contamination of maize hybrids visibly damaged by Sesamia. J Sci Food Agric 2002, 83:13-18.

4. Butron A, Santiago R, Mansilla P, Pintos-Varela C, Ordas A, Malvar RA: Maize (Zea mays L.) genetics factors for preventing fumonisin contamination. J Agr Food Chem 2006, 54:6113-6117.

5. Malvar RA, Butron A, Alvarez A, Ordas B, Soengas P, Revilla P, Ordas A: Evaluation of the European Union maize landrace core collection for resistance to Sesamia nonagrioides (Lepidoptera: Noctuidae) and Ostrinia nubilalis (Lepidoptera. Crambidae). J Econ Entomol 2004, 97:628-634.

6. Velasco P, Malvar RA, Revilla P, Butron A, Ordas A: Ear resistance of sweet corn populations to Sesamia nonagrioides (Lepidoptera: Noctuidae) and Ostrinia nubilalis (Lepidoptera: Pyralidae). J Econ Entomol 1999, 92:732-739.

7. Cardinal AJ, Lee M, Sharopova N, Woodman WL, Long MJ: Genetic mapping and analysis of quantitative trait loci in maize for resistance to stalk tunnelling by the European corn borer. Crop Sci 2001, 41:835-845.

8. Jampatong C, McMullen MD, Barry BD, Darrah LL, Byrne PF, Kross H: Quantitative trait loci for first- and second-generation European corn borer resistance from the maize inbred line Mo47. Crop Sci 2002, 42:584-593.

9. Krakowsky MD, Lee M, Woodman-Clikeman WL, Long MJ, Sharopova N: QTL mapping of resistance to stalk tunnelling by the European corn 
borer in RILs of maize population B73 × De811. Crop Sci 2004, 44:274-282.

10. Ordas B, Malvar RA, Santiago R, Sandoya G, Romay MC, Butron A: Mapping of QTL for resistance to the Mediterranean corn borer attack using the intermated B73 $\times$ Mo17 (IBM) population of maize. Theor Appl Genet 2009, 119:1451-1459.

11. Holland JB: Genetic architecture of complex traits in plants. Curr Opin Plant Biol 2007, 10:156-161.

12. Malvar RA, Cartea ME, Revilla P, Ordas A, Alvarez A, Mansilla JP: Sources of resistance to pink stem borer and European corn borer in maize. Maydica 1993, 38:313-319.

13. Ordas A, Alvarez A, Malvar RA: Variability of resistance to the second generation of European corn borer in maize. Maydica 1988, 33:27-36.

14. Butron A, Malvar RA, Velasco P, Vales MI, Ordas A: Combining abilities for maize stem antibiosis, yield loss, and yield under infestation and non infestation with pink stem borer. Crop Sci 1999, 39:691-696.

15. Butron A, Sandoya G, Revilla P, Malvar RA: Genetics of resistance to the pink stem borer (Sesamia nonagrioides Lef.) in maize (Zea mays L.). Ann Appl Biol 2009, 154:205-215.

16. Cartea ME, Malvar RA, Butron A, Vales Ml, Ordas A: Inheritance of antibiosis to Sesamia nonagrioides (Lepidoptera: Noctuidae) in maize. J Econ Entomol 1999, 92:994-998.

17. Butron A, Malvar RA, Velasco P, Cartea ME, Ordas A: Combining abilities and reciprocal effects for maize ear resistance to pink stem borer. Maydica 1998, 43:117-122.

18. Cartea ME, Malvar RA, Vales Ml, Butron A, Ordas A: Inheritance of resistance to ear damage caused by Sesamia nonagrioides (Lepidoptera: Noctuidae) in maize. J Econ Entomol 2001, 94:277-283.

19. Klenke JR, Russell WA, Guthrie WD: Grain yield reduction caused by second-generation European corn borer in BS9 corn synthetic. Crop Sci 1986, 26:859-863.

20. Russell WA, Lawrence GD, Guthrie WD: Effects of recurrent selection for European corn borer resistance on other agronomic characters in synthetic cultivars of corn. Maydica 1979, 24:33-47.

21. Sandoya G, Butron A, Alvarez A, Ordas A, Malvar RA: Direct response of a maize synthetic to recurrent selection for resistance to stem borers. Crop Sci 2008, 48:113-118.

22. Moreno-Gonzalez J, Martinez I, Brichette I, Lopez A, Castro P: Breeding potential of European flint and US corn belt dent maize populations for forage use. Crop Sci 2000, 40:1588-1595.

23. Reif JC, Hallauer AR, Melchinger AE: Heterosis and heterotic patterns in maize. Maydica 2005, 50:215-223.

24. Soengas P, Ordas B, Malvar RA, Revilla P, Ordas A: Heterotic patterns among flint maize populations. Crop Sci 2003, 43:844-849.

25. Soengas $P$, Ordas B, Malvar RA, Revilla P, Ordas A: Combining abilities and heterosis for adaptation in flint maize populations. Crop Sci 2006, 46:2666-2669.

26. Ordas A: Heterosis in crosses between American and Spanish populations of maize. Crop Sci 1991, 31:931-935

27. Reif JC, Fischer S, Schrag TA, Lamkey KR, Klein D, Dhillon BS, Utz HF, Melchinger AE: Broadening the genetic base of European maize heterotic pools with US Cornbelt germplasm using field and molecular marker data. Theor Appl Genet 2010, 120:301-310.

28. Soengas $\mathrm{P}$, Ordas B, Malvar RA, Revilla P, Ordas A: Performance of flint maize in crosses with testers from different heterotic groups. Maydica 2003, 48:85-91.

29. Butron A, Malvar RA, Cartea ME, Ordas A, Velasco P: Resistance of maize inbreds to pink stem borer. Crop Sci 1999, 39:102-107.

30. Ordas B, Butron A, Soengas P, Ordas A, Malvar RA: Antibiosis of the pith maize to Sesamia nonagrioides (Lepidoptera: Noctuidae). J Econ Entomol 2002, 95:1044-1048.

31. Velasco P, Soengas P, Revilla P, Ordás A, Malvar RA: Mean generation análisis of damage caused by Sesamia nonagrioides (Lepidoptera: Noctuidae) and Ostrinia nubilalis (Lepidoptera: Crambidae) in sweet corn ears. J Econ Entomol 2004, 97:120-126.

32. Soengas $P$, Butron A, Revilla P, Ordas A, Malvar RA: Performance of crosses among flint maize populations under infestation by Sesamia nonagrioides (Lepidoptera: Noctuidae). J Econ Entomol 2004, 97:1438-1443.

33. Schon CC, Lee M, Melchinger AE, Guthrie WD, Woodman WD: Mapping and characterization of quantitative trait loci affecting resistance against second-generation European corn borer in maize with the aid of RFLPs. Heredity 1993, 70:648-659.

34. Papst C, Bohn M, Utz HF, Melchinger AE, Klein D, Elder J: QTL mapping for European corn borer and forage quality traits of testcross progenies in early-maturing European maize (Zea mays L.) germplasm. Theor Appl Genet 2004, 108:1545-1554

35. Krakowsky MD, Brinkman MJ, Woodman-Clikeman WL, Lee M: Genetic component of resistance to stalk tunnelling by the European corn borer in maize. Crop Sci 2002, 42:1309-1315.

36. Bergvinson DJ, Hamilton RI, Arnason JT: Leaf profile of maize resistance factors to European corn borer Ostrinia nubilalis. J Chem Ecol 1995, 21:343-354.

37. Ostrander BM, Coors JG: Relationship between plant composition and European corn borer resistance in three maize populations. Crop Sci 37:1741-1745.

38. Rojanaridpiched C, Gracen VE, Everett HL, Coors JG, Pugh BF, Bouthyette P: Multiple factor resistance in maize to European corn borer. Maydica 1984, 29:305-315.

39. Santiago R, Butron A, Arnason JT, Reid LM, Souto XC, Malvar RA: Putative role of pith cell wall phenylpropanoids in Sesamia nonagrioides (Lepidoptera: Noctuidae) resistance. J Agric Food Chem 2006, 54:2274-2279.

40. Bernays EA: Diet-induced head allometry among foliage-chewing insects and its importante for graminivores. Science 1986, 231:495-497.

41. Raupp MJ: Effects of leaf toughness on mandibular wear of the leaf beetle, Plagiodera versicolora. Ecol Entomol 1985, 10:73-79.

42. Flint-Garcia SA, Jampatong Ch, Darrah LL, McMullen MD: Quantitative trait locus analysis of stalk strength in four maize populations. Crop Sci 2003, 43:13-22.

43. Barriere $Y$, Thomas J, Denouse D: QTL mapping for lignin content, lignin monomeric composition, p-hydroxycinnamate content, and cell wall digestibility in the maize recombinant inbred line progeny F838 × F286. Plant Sci 2008, 175:585-595

44. Cardinal AJ, Lee M, Moore KJ: Genetic mapping and analysis of quantitative trait loci affecting fiber and lignin content in maize. Theor Appl Genet 2003, 106:866-874.

45. Fontaine AS, Briand M, Barriere Y: Genetic variation and QTL mapping of para-coumaric and ferulic acid contents in maize stover at silage harvest. Maydica 2003, 48:75-84.

46. Krakowsky MD, Lee M, Coors JG: Quantitative trait loci for cell-wall components in recombinant inbred lines of maize (Zea mays L.): stalk tissue. Theor Appl Genet 2005, 111:337-346.

47. Riboulet C, Fabre F, Denoue, Martinant JP, Lefevre B, Barriere Y: QTL mapping and candidate gene research for lignin content and cell wall digestibility in a top-cross of a flint maize recombinant inbred line progeny harvested at silage stage. Maydica 2008, 53:1-9.

48. Barriere Y, Guillet C, Goffner d, Pichon M: Genetic variation and breeding strategies for improved cell wall digestibility in annual forage crops. A review. Animal Research 2003, 52:193-228.

49. Roussel V, Gibelin C, Fontaine AS, Barriere Y: Genetic analysis in recombinant inbred lines of early dent forage maize. II - QTL mapping for cell wall constituents and cell wall wall digestibility from per se value and top cross experiments. Maydica 2002, 47:9-20.

50. Shi C, Uzarowska A, Ouzunova M, Landbeck M, Wenzel G, Lubberstedt T: Identification of candidate genes associated with cell wall digestibility and eQTL (expression quantitative trait loci) analysis in a Flint $\times$ Flint maize recombinant inbred line population. BMC Genomics 2007, 8:22-37.

51. Andersen JR, Zein I, Wenzel g, Darnhofer B, Eder J, Ouzunova M, Lubberstedt T: Characterization of phenylpropanoid pathway genes within European maize (Zea mays L.) inbreds. BMC Plant Biol 2008, 8:2-15.

52. Delmer DP, Haigler $\mathrm{CH}$ : The regulation of metabolic flux to cellulose, a major sink for carbon in plants. Metab Eng 2002, 4:22-28.

53. Schichnes DE, Freeling M: Lax midrib1-O, a systemic, heterochronic mutant of maize. Am J Bot 1998, 85:481-491.

54. Falkner LK, Coors JG, Ostrander BM, Kaeppler SM, Hatfield RD: Lax leaf maize: cell wall composition and nutritional value. J Sci Food Agric 2000, 80:255-262.

55. Sneller $\mathrm{CH}$, Mather $\mathrm{DE}$, Crepieux S: Analytical approaches and population types for finding and utilizing QTL in complex plant populations. Crop Sci 2009, 49:363-380. 
56. Chardon F, Virlon B, Moreau L, Falque M, Joets J, Decousset L, Murigneux A, Charcosset A: Genetic arquitecture of flowering time in maize as inferred from quantitative trait loci meta-analysis and synteny conservation with the rice genome. Genetics 2004, 168:2169-2185.

57. Salvi S, Sponza G, Morgante M, Tomes D, Niu X, Fengler KA, Meeley R, Ananiev EV, Svitashev S, Bruggemann E, Li B, Hainey CF, Radovic S, Zaina G, Rafalski JA, Tingey SV, Miao GH, Phillips RL, Tuberosa R: Conserved noncoding genomic sequences associated with a flowering-time quantitative trait locus in maize. Proc Natl Acad Sci USA 2007, 27:11376-11381.

58. Chardon F, Hourcade D, Combes V, Charcosset A: Mapping of a spontaneous mutation for early flowering time in maize highlights contrasting allelic series at two-linked QTL on chromosome 8. Theor Appl Genet 2005, 112:1-11.

59. Beavis WD, Grant $D$, Albertsen M, Fincher R: Quantitative trait loci for plant height in 4 maize populations and their associations with qualitative genetic loci. Theor Appl Genet 1991, 83:141-145.

60. Lubberstedt T, Melchinger AE, Fahr S, Klein D, Dally A, Weshoff P: QTL mapping in testcrosses of flint lines of maize: III. Comparison across populations for forage traits. Crop Sci 1998, 38:1278-1289.

61. Yan JB, Tang H, Huang YQ, Shi YG, Li JS, Zheng YL: Dynamic analysis of QTL for plant height at different developmental stages in maize (Zea mays L.). Chinese Science Bulletin 2003, 48:2601-2607.

62. Frascaroli E, Cane MA, Pe ME, Pea G, Morgante M, Landi P: QTL detection in maize testcross progenies as affected by related and unrelated testers. Theor Appl Genet 2009, 118:993-1004.

63. Butron A, Malvar RA, Velasco P, Revilla P, Ordas A: Defense mechanisms of maize against pink stem borer. Crop Sci 1998, 38:1159-1163.

64. SAS, Version 9.1.3 SAS Institute Cary, NC 2003.

65. Holland JB: Estimating genotypic correlations and their Standard errors using multivariated restricted maximum likelihood estimation with SAS Proc Mixed. Crop Sci 2006, 46:642-654.

66. Liu YG, Whittier RF: Rapid preparation of megabase plant DNA from nuclei in agarose plugs and microbeads. Nucleic Acids Res 1994, 22:2168-2169.

67. Butron A, Tarrio R, Revilla P, Malvar RA, Ordas A: Molecular evaluation of two methods for developing maize synthetic varieties. Mol Breed 2003, 12:329-333.

68. Wang D, Shi J, Carlson SR, Cregan PB, Ward RW, Diers BW: A low-cost, high-throughput polyacrylamide gel electrophoresis system for genotyping with microsatellite DNA markers. Crop Sci 2003, 43:1828-1832.

69. Lander ES, Green P, Abrahamson J, Barlow A, Daly MJ, Lincoln SE, Newburg L: MAPMAKER: an interactive computer package for constructing primary genetic linkage maps of experimental and natural populations. Genomics 1987, 1:174-181.

70. Voorrips RE: Mapchart: Software of the graphical presentation of linkage maps and QTLs. J Hered 2002, 93:77-78.

71. Zeng ZB: Precision mapping of quantitative trait loci. Genetics 1994, 136:1457-1468.

72. Utz HF, Melchinger AE: PLABQTL. A computer program to map QTL. J QuantTrait Loci 1996, 2:1.

73. Utz HF, Melchinger AE: A computer program to map QTL.https://www.unihohenheim.de/plantbreeding/software/plabqtl/plabqtl_manual.pdf.

74. Utz HF, Melchinger AE, Schon CC: Bias and sampling error of the estimated proportion of genotypic variance explained by quantitative trait loci determined from experimental data in maize using cross validation with independent samples. Genetics 2000, 154:1839-1849.

doi:10.1186/1471-2164-11-174

Cite this article as: Ordas et al: QTL mapping for Mediterranean corn borer resistance in European flint germplasm using recombinant inbred lines. BMC Genomics 2010 11:174.

\section{Submit your next manuscript to BioMed Central and take full advantage of:}

- Convenient online submission

- Thorough peer review

- No space constraints or color figure charges

- Immediate publication on acceptance

- Inclusion in PubMed, CAS, Scopus and Google Scholar

- Research which is freely available for redistribution

Submit your manuscript at www.biomedcentral.com/submit
Biomed Central 